Article

\title{
Climate Change Impacts on a Tropical Fishery Ecosystem: Implications and Societal Responses
}

\author{
Mohammad Mahmudul Islam 1,*(D), Naimul Islam ${ }^{1}$, Ahasan Habib ${ }^{2,3}$ (D) and \\ Mohammad Mojibul Hoque Mozumder 4 (i) \\ 1 Department of Coastal and Marine Fisheries, Sylhet Agricultural University, Sylhet 3100, Bangladesh; \\ naimul.mer@gmail.com \\ 2 Faculty of Fisheries and Food Science, Universiti Malaysia Terengganu, Kuala Nerus, \\ Terengganu 21030, Malaysia; a.habib@umt.edu.my \\ 3 Department of Fisheries and Marine Science, Noakhali Science and Technology University, \\ Noakhali 3814, Bangladesh \\ 4 Helsinki Institute of Sustainability Science (HELSUS), Fisheries and Environmental Management Group, \\ Faculty of Biological and Environmental Sciences, University of Helsinki, 00014 Helsinki, Finland; \\ mohammad.mozumder@helsinki.fi \\ * Correspondence: mahmud.cmf@sau.ac.bd; Tel.: +88-0821-761625
}

Received: 23 July 2020; Accepted: 29 August 2020; Published: 25 September 2020

check for updates

\begin{abstract}
The present study aimed to map out the current threats and anticipated impacts of climate change on the most important hilsa shad (Tenualosa ilisha) fishery and the associated fishing communities based on fieldwork in six coastal fishing communities. To collect empirical data, individual interviews, focus group discussions, oral history, and key informant interviews were conducted. To supplement the empirical findings, time-series data of cyclones and sea-borne depressions in the Bay of Bengal were also analyzed. Analysis of secondary data regarding climate change-induced events and regional studies suggested that the biophysical conditions of the Bay of Bengal are likely to be aggravated in the future, potentially causing more frequent extreme events and affecting the livelihoods of coastal fishing communities in Bangladesh. The fisher respondents revealed that the main target hilsa shad fishery is particularly vulnerable to climate change in terms of alterations to migration patterns and breeding and growth performance. The fishers reported constant climate-related risks because they live in seafront locations, exposed to extreme events, and their occupation entails risky sea fishing. Fishers claimed that they often need return to the coast due to unsuitable weather conditions related to cyclones and frequent tropical depressions, which can cause financial losses or even causalities. Such events negatively affect fishers' livelihoods, and wellbeing. To cope with the impacts of climate change the fishers have adopted various strategies at both sea fishing and household levels. However, these strategies only support the fishers in terms of immediate survival; they are not enough for long-term resilience. To improve the resilience of the hilsa fishers, the study argues for the implementation the Small-Scale Fisheries Guidelines (SSF Guidelines), which call for longer-term development goals, including in the immediate relief phase, and rehabilitation, reconstruction, and recovery to reduce vulnerabilities to climate and anthropogenic risks.
\end{abstract}

Keywords: tropical fishery; hilsa shad fishery; climate change; adaptation; small-scale fisheries guidelines

\section{Introduction}

Climate change currently poses as one of the greatest threats to global biodiversity [1,2]. The fifth report of the Intergovernmental Panel on Climate Change (IPCC-AR5) has predicted that due to 
anticipated climate change, by the mid-21st century and beyond, marine species will redistribute their niches. Consequently, marine biodiversity will be reduced in climate-sensitive regions, challenging the flow of fisheries and other ecosystem services [3]. Marine species are shifting due to temperature increases $[4,5]$, placing additional pressure on fishery systems, which are already experiencing overfishing, habitat loss, pollution, and other stresses [6,7]. The unpredictable impacts of climate change, coupled with existing stressors such as overfishing or habitat degradation, may provide complications for fisheries managers [8,9]. Climate change is expected to both directly and indirectly affect marine and freshwater fisheries, with consequences for economies dependent on fisheries, coastal fishing populations, and ecosystems [10]. Coastal communities in developing countries in tropical regions have been identified as particularly vulnerable to climate change, for several reasons: for instance, they are highly dependent economically and nutritionally on fish and they lack resources to enhance their adaptability to climate change [11,12]. Economic returns from fishers' livelihood strategies have been significantly implicated by climate change's impacts and variability. This, in turn, can affect household and community vulnerability and adaptive capacity [13]. Overall, climate change is likely to have significant consequences for fisheries and will affect the livelihoods and security of millions of people around the world [9]. Although these impacts are felt at the global scale, tropical marine habitats and fish stocks are particularly vulnerable, necessitating a comprehensive understanding of the risks of climate change in the tropical region for better informed responses [14].

Bangladesh is ranked 18th in terms of national vulnerability to the impacts of climate change on marine fisheries [15] because of its low-lying topography, climate-sensitive agrarian economy, widespread poverty, high population density, and poor governance. Of these reasons, Bangladesh's geophysical setting is the reason that primarily explains the country's susceptibility to the effects of climate change and that also renders it extremely hard to protect. The country's coast is experiencing rising sea levels $[16,17]$. Only $10 \%$ of Bangladesh's land is one meter or more above the mean sea level, while one-third is under tidal influence and, thus, susceptible to serious natural disasters, such as tropical cyclones [18]. Climate change is significantly challenging the country's ability to achieve high economic growth [19]. The coastal fisheries-dependent population of Bangladesh is exceptionally vulnerable to climate change, which is likely to threaten the country's water and fishery resources [20].

Consequently, adaptation is necessary to challenge the shocks and stresses posed by climate change [20]. Although societies, including their fishing communities, do not sit idly by but rather continuously adapt to changing climatic conditions via different strategies, the efficacy of any response is not consistent across space [21]. Fishing communities are particularly vulnerable because they live close to the coast in order to enjoy easy access to fishing grounds; they also depend on climate-sensitive fisheries resources and their social position can often be defined as underprivileged [22]. Therefore, fishing communities deserve more attention within climate change adaptation debates, as they face complex climate change impacts, along with non-climatic pressures [7]. Again, it is important to recognize that not all fishing communities are equally vulnerable, as vulnerability is context-specific. Communities that are dependent on local supplies of just a few species are likely to become especially susceptible to stock fluctuation, whether due to overfishing, climate variability or other causes [23]. A crucial point in understanding fishers' vulnerability is that communities dependent on fisheries are likely to experience increased vulnerability due to higher volatility in catches and incomes, changes in the quantity and quality of fish and risks to their safety [24]. Overall, climate change is expected to have enormous implications for fisheries and affect millions of people worldwide [9].

\section{Hilsa (Tenualosa Ilisha) Fisheries: Biology, Ecosystem, and Society}

Hilsa shad (Tenualosa ilisha) is a euryhaline anadromous fish species, which is found in marine, coastal, estuarine, and freshwater environments. The species is distributed across a large part of the tropical ecosystem, from the Strait of Malacca near Malaysia to the Euphrates River in Iraq. The fishery stock of hilsa shad is also shared with India and Myanmar, although only Bangladesh has been trying to improve the stock through effective conservation initiatives [25]. The habitat in Bangladesh covers the 
Bay of Bengal's coastal and marine waters and all major coastal rivers, including the Padma, the Jamuna, and the Meghna. This fast-swimming species [26] can travel vast distances upstream: $50-100 \mathrm{~km}$ is usually reasonable in Bangladesh's rivers. Favorable water conditions are prerequisites for successful spawning. The most suitable temperature range for spawning is $20-25^{\circ} \mathrm{C}$, with $0-2$ ppt salinity and $>5$ ppm dissolved oxygen. Rainfall is an essential factor for the breeding of hilsa. The suitable range of rainfall varies between 150 and $300 \mathrm{~mm} / \mathrm{m}$ [27]. After spawning, the eggs are deposited in fresh water; hatching then takes place within $23-26 \mathrm{~h}$ at an average temperature of $23^{\circ} \mathrm{C}$. For 5-6 months, larvae and juveniles start their migration downstream. In about 6-10 weeks, fry grows to about $12-20 \mathrm{~cm}$ and becomes juvenile (locally known as jatka). At this stage, the juveniles start migrating to marine waters for further growth and maturity. After spending a year in the sea, hilsa become mature and begin migrating back towards inland rivers for spawning [28]. Generally, the growth of hilsa varies from one ecosystem to another or even in the same environment due to differences in ecology, food availability, habitat characteristics, population size, and density-dependent growth factors [29].

Hilsa is the national fish of Bangladesh and constitutes the largest and most important fishery in Bangladesh, contributing $12.09 \%$ (in 2017-2018) of total fish production and 1\% to the Gross Domestic Product [30]. The economic, social, and cultural importance of hilsa is immense. About half a million fishers are directly engaged in hilsa fishing. An additional 2.5 million people are indirectly involved in the hilsa sector through boat and gear making, fish transport, ice production, fish processing, trading and export [27]. Hilsa fishers are the most vulnerable and most impoverished communities in Bangladesh due to their incomes being below the marginal level [31,32]. They remain vulnerable to disasters of waterborne origin. During rough weather fishing, casualties are frequent and policy makers still fail to pay adequate attention [33]. Dependence on hilsa fisheries is very high and the hilsa species is threatened by climatic variability [34]. Using the sustainable livelihood approach (SLA) as a theoretical lens, the present study aims to extrapolate the potential changes of climate and their impacts on fishers' livelihood assets, emphasizing the natural capital of hilsa fisheries. The study also assesses the affected communities and the government's response to address their vulnerability to climate change.

\section{Sustainable Livelihood Approach (SLA): A Framework for Analyzing Fishers' Livelihoods}

Livelihood is defined as the capabilities, assets, and activities that constitute a person's means of living [35]. The sustainable livelihood concept seeks to bring together the assets, events and critical factors that affect household strategies' vulnerability or strength [36,37]. A livelihood is sustainable if it can cope with and recover from stresses and shocks and maintain or enhance its capabilities and asset base both now and in the future, without undermining its natural resource base [38]. Using the SLA for developing adaptation strategies and initiatives will ensure a people-oriented and bottom-up approach to adaptation, which tackles potential climate change by reducing existing vulnerabilities [39]. The SLA is particularly relevant to understanding climate change vulnerability as it provides a framework for analyzing the principal components (that make up livelihoods) and the contextual factors that influence them. They are closely linked to the elements that make a household or community more sensitive or exposed to climate change impacts and that affect their ability to cope with environmental change [40].

Globally, 39 million people are employed in capture fisheries [41] and about $90 \%$ of them work in the small-scale fisheries sector [42]. However, small-scale fisheries (SSF) are exposed to uncertainty in supply and demand and fishing activities are usually influenced by social and institutional factors that qualify the SLA as a beneficial form of fisheries management [37]. Through understanding climate change adaptation at the community level, the SLA can provide insights into small-scale fisheries management in developing countries [40,43]. Indeed, the livelihood status and sustainability of fishing communities can be analyzed more effectively through the SLA framework. According to this framework (Figure 1), a fishery-based livelihood including fishers' individual or household assets, activities, and strategies produces more livelihood outcomes, generates more income, and improves food security. 


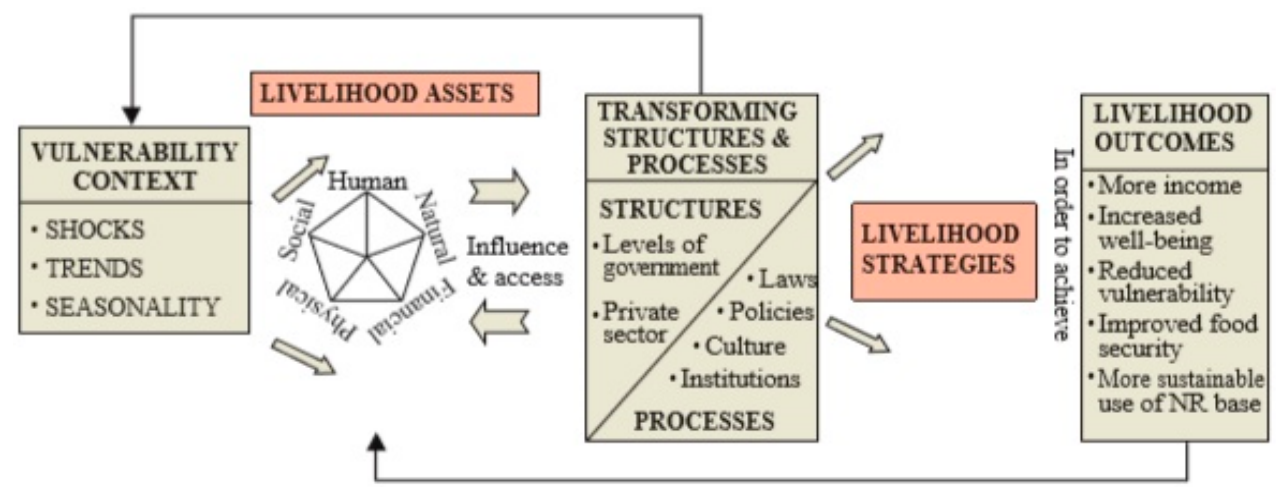

Figure 1. Sustainable Livelihood Approach (SLA) framework [44].

Natural capital refers to the natural resources (e.g., fish stock, aquatic habitats, freshwater source) from which fishing people accrue benefits [45]. Physical capital refers to the types of tools or equipment and infrastructure that are used to support livelihoods: for example, fisheries-related resources such as fish landing centers, ice plants, boats, engines, gears, processing plants, and equipment as well as non-fisheries-related resources such as roads, houses, schools, markets, hospitals, water supply systems, and cyclone shelters [37,45]. In addition, knowledge, fishing skills, and physical ability are considered as human capital. Moreover, social capital refers to social resources such as membership in cooperative organizations or political parties, kinship, and trading linkages [45], while financial capital refers to the financial resources that people use to achieve their livelihood objectives, such as cash, bank deposits and remittances [43].

\section{Materials and Methods}

This research was based on both primary data and secondary data. Using a semi-structured questionnaire, primary data were collected from six coastal communities in Bangladesh. The study sites were: Hatempur in Barguna district; Fatapur, Mahipur and Char Gangamoti in Patuakhali district; Laharhut in Barisal district; and Char Kukri Mukri in Bhola district (Table 1 and Figure 2). The study was conducted in three phases from January 2016 to April 2016, October 2016 to December 2016, and February 2017 to March 2017. The main selection criteria were the settlements' fishers' livelihood characteristics, the dependency level of communities on fisheries, and their exposure to past climatic effects. This study adopted a mixed-methods approach, comprising both quantitative methods like semi-structured questionnaires and qualitative methods comprising oral history interviews, key informant interviews, and focus group discussions.

Table 1. Source of primary information, study sites sampled, methods used, and sample size.

\begin{tabular}{|c|c|c|c|c|c|c|}
\hline \multicolumn{2}{|r|}{ Study Sites } & \multirow{2}{*}{$\begin{array}{l}\text { Geographical Position } \\
\text { System Location }\end{array}$} & \multicolumn{4}{|c|}{$\begin{array}{c}\text { Data Collection Methods and } \\
\text { Sample Size }\end{array}$} \\
\hline District & Location (Sub-District) & & II & KII & $\mathrm{OH}$ & FGD \\
\hline Barguna & Hatempur (Patharghata) & $22^{\circ} 03^{\prime} 06^{\prime \prime} \mathrm{N}, 89^{\circ} 56^{\prime} 59^{\prime \prime} \mathrm{E}$ & 30 & 5 & 3 & 2 \\
\hline Patuakhali & Char Gangamoti (Kalapara) & $21^{\circ} 48^{\prime} 52^{\prime \prime} \mathrm{N}, 90^{\circ} 13^{\prime} 06^{\prime \prime} \mathrm{E}$ & 20 & 4 & 4 & 1 \\
\hline Patuakhali & Fatapur (Kalapara) & $21^{\circ} 57^{\prime} 54^{\prime \prime} \mathrm{N}, 90^{\circ} 08^{\prime} 50^{\prime \prime} \mathrm{E}$ & 20 & 5 & 3 & 2 \\
\hline Patuakhali & Mahipur Bazar (Kalapara) & $21^{\circ} 51^{\prime} 29^{\prime \prime} \mathrm{N}, 90^{\circ} 07^{\prime} 34^{\prime \prime} \mathrm{E}$ & 20 & 5 & 4 & 1 \\
\hline Barisal & Laharhut (Barisal Sadar) & $22^{\circ} 40^{\prime} 09^{\prime \prime} \mathrm{N}, 90^{\circ} 28^{\prime} 18^{\prime \prime} \mathrm{E}$ & 15 & 3 & 4 & 2 \\
\hline Bhola & Char Kukri Mukri (Char Fesson) & $21^{\circ} 56^{\prime} 00^{\prime \prime} \mathrm{N}, 90^{\circ} 38^{\prime} 45^{\prime \prime} \mathrm{E}$ & 45 & 5 & 3 & 3 \\
\hline \multicolumn{3}{|c|}{ Total } & 150 & 27 & 24 & 11 \\
\hline
\end{tabular}

$\mathrm{II}=$ individual interview, $\mathrm{KII}=$ key informant interview, $\mathrm{OH}=$ oral history FGD = focus group discussion. 




Figure 2. Location of study sites in coastal Bangladesh.

The questionnaire was designed based on the specific context of coastal fishing communities in Bangladesh. Only household heads (who are male) were interviewed because they were deemed knowledgeable of their household's vulnerability, security and livelihood [45]. A total of 150 in-depth interviews were conducted. The key informants included individuals from inside (i.e., community leaders and members with relevant knowledge) and outside (i.e., government officials, Non-Government Organizations-NGOs/development organizations and researchers) the communities. Twenty-seven key informant interviews were conducted during the data collection process. Eleven focus group discussions (FGDs) were conducted in all study areas, involving seven to ten fishers per session. Each FGD session ran for about 45 to $60 \mathrm{~min}$. Twenty-four oral history interviews were also conducted. Among the respondents, $10 \%$ respondents were less than 18 years old. Most of the respondents $(71.33 \%)$ were 18 to 40 years old. Another $10 \%$ fishers were in the 41 to 50 range. The remaining $8.67 \%$ respondents were over 50 years old. The majority of hilsa fishers belonged to a joint family with an average household size of 5.9 persons, higher than the national average (4.6 persons) [46]. 
The meteorological data for assessing climate change trends were collected from the Bangladesh Meteorological Department (BMD) Dhaka. Other data were mainly collected from secondary sources, including official documents and statistics, and reports by the government, NGOs, and other relevant organizations. The data were analyzed using Microsoft Excel and SPSS 20. Analysis of the qualitative data involved triangulating the information obtained from field notes, transcribed interviews, and secondary sources. Data were coded according to predetermined themes (developed intrinsically from the interview texts), and analyzed using content analysis to extract the main findings.

\section{Results and Discussion}

\subsection{Regional (Physical) Prediction of Climate Change and Variability}

According to the IPCC-AR5, warming in South Asia is likely to exceed the global average of around $3.3^{\circ} \mathrm{C}$. Warming is predicted to be significant from 1.6 to $2{ }^{\circ} \mathrm{C}$ by 2050 [47]. The National Adaptation Program of Action (NAPA) of Bangladesh has predicted 1.0, 1.4, and $2.4^{\circ} \mathrm{C}$ temperature rises by 2030, 2050, and 2100, respectively [48]. The projection of the regional climate model (RCM) has indicated a consistent increase in temperature throughout the 21st century in Bangladesh [46]. By the $2060 \mathrm{~s}$, the temperature is projected to increase by between 1.5 and $2.7^{\circ} \mathrm{C}$, ranging between 2.6 and $4.8^{\circ} \mathrm{C}$ by the 2090s [46]. A study projected SST about $30.8^{\circ} \mathrm{C}$ in 2030 and $31.7^{\circ} \mathrm{C}$ after 2050 in the Bay of Bengal [32]. According to the IPCC, rainfall in South Asia is predicted to increase by $5-7 \%$ in the $2020 \mathrm{~s}$, $10-13 \%$ in the 2050s, and 15-26\% in the 2080s [47]. The rate of sea-level rise (SLR) along Bangladesh's coast has been found to be much higher than the global average of 1.0-2.0 mm/year in the 20th century. Based on IPCC reports and other studies, the NAPA has anticipated SLRs of 14, 32, and $88 \mathrm{~cm}$ for 2030, 2050 and 2100, respectively [48]. As a possible implication, future storm surges may be even higher than those experienced presently due to the combined effects of increased temperature and rising sea level. According to the IPCC, the ocean will continue to warm and acidify, with negative implications for marine wildlife and fisheries [49]. As a result of rising sea levels, communities in low-lying areas will face coastal flooding from storm surges. They will also experience more frequent and acute health problems due to heat waves.

The species distributions will affect functional diversity (related to the ecological functions and services played by the species) due to climate-driven changes [50]. Climate change impacts under greenhouse emissions scenario A1B are likely to reduce the potential production of the hilsa population by $10 \%$ in the Bangladesh Exclusive Economic Zone (EEZ); moreover, even under sustainable management practices, a significant $(25 \%)$ decline in hilsa catch is expected by 2060 [32]. Fernandes et al. (2016) have added that if overexploitation is allowed, the catches are projected to fall even further, by almost $95 \%$ by 2060 [32]. Potentially, the hilsa population will be severely affected, including in terms of its spawning grounds and juvenile survival rate due to climate change and anthropogenic activities.

\subsection{Current Processes of Environmental Risks Resulting from Extreme Events in the Bay of Bengal}

According to the BMD data, the country frequently suffered severe cyclonic storms from 1985 to 2015 (Table 2). During the last 30-year period, tropical cyclones have registered an increase in annual frequency by 0.006 cyclones per year. During this period, the Bay of Bengal has produced about 77 severe cyclonic storms (average 3.48 storms per year) with an average wind speed of $175.84 \mathrm{~km} / \mathrm{h}$. Moreover, several severe cyclonic storms with a core of hurricane wind have been observed in the last 55 years. Among them, the cyclones in 1970, 1988, 1991, 1994, 1997, and 1998 caused enormous losses and had maximum wind speeds of $224 \mathrm{~km} / \mathrm{h}, 160 \mathrm{~km} / \mathrm{h}, 225 \mathrm{~km} / \mathrm{h}, 278 \mathrm{~m} / \mathrm{h}$, $232 \mathrm{~km} / \mathrm{h}$, and $173 \mathrm{~km} / \mathrm{h}$, respectively. 
Table 2. List of devastating cyclonic storms in each year from 1960 to 2017 [51].

\begin{tabular}{|c|c|c|c|}
\hline $\begin{array}{c}\text { Date of } \\
\text { Occurrence }\end{array}$ & Nature of Phenomenon & $\begin{array}{l}\text { Maximum Wind } \\
\text { Speed in km/h }\end{array}$ & $\begin{array}{l}\text { Tidal Surge } \\
\text { Height in } \mathrm{ft} .\end{array}$ \\
\hline 31.10 .60 & Severe cyclonic storm & 193 & 20 \\
\hline 30.05 .61 & Severe cyclonic storm & 160 & $6-15$ \\
\hline 28.05 .63 & Severe cyclonic storm & 209 & $8-12$ \\
\hline 15.12 .65 & Severe cyclonic storm & 210 & $8-10$ \\
\hline 01.11 .66 & Severe cyclonic storm & 120 & $20-22$ \\
\hline 12.11.70 & $\begin{array}{l}\text { Severe cyclonic storm } \\
\text { with a hurricane wind }\end{array}$ & 224 & $10-33$ \\
\hline 28.11 .74 & Severe cyclonic storm & 163 & 9-17 \\
\hline 09.11 .83 & Severe cyclonic storm & 136 & 5 \\
\hline 24.05 .85 & Severe cyclonic storm & 154 & 15 \\
\hline 29.11.88 & $\begin{array}{l}\text { Severe cyclonic storm } \\
\text { with a hurricane wind }\end{array}$ & 160 & $2-14.5$ \\
\hline 29.04 .91 & $\begin{array}{l}\text { Severe cyclonic storm } \\
\text { with a hurricane wind }\end{array}$ & 225 & $12-22$ \\
\hline 02.05 .94 & $\begin{array}{l}\text { Severe cyclonic storm } \\
\text { with a hurricane wind }\end{array}$ & 278 & $5-6$ \\
\hline 25.11 .95 & Severe cyclonic storm & 140 & 10 \\
\hline 19.05 .97 & $\begin{array}{l}\text { Severe cyclonic storm } \\
\text { with a hurricane wind }\end{array}$ & 232 & 15 \\
\hline 20.05 .98 & $\begin{array}{l}\text { Severe cyclonic storm } \\
\text { with a hurricane wind }\end{array}$ & 173 & 3 \\
\hline 15.11.07 & $\begin{array}{l}\text { Severe cyclonic storm } \\
\text { (Sidr) }\end{array}$ & 223 & $15-20$ \\
\hline 25.05 .09 & Cyclonic storm (Aila) & $70-90$ & $4-6$ \\
\hline 16.05 .13 & $\begin{array}{l}\text { Cyclonic storm } \\
\text { (Mahasen) }\end{array}$ & 100 & - \\
\hline 30.07 .15 & Cyclonic storm (Komen) & 65 & $5-7$ \\
\hline 21.05 .16 & $\begin{array}{l}\text { Tropical cyclonic storm } \\
\text { (Roanu) }\end{array}$ & 110 & $8.2-8.9$ \\
\hline 28.05 .17 & Cyclonic storm (Mora) & 111 & $5.5-6.5$ \\
\hline
\end{tabular}

Analysis of the 40 years of data (1975-2015) revealed that Bangladesh experienced many tropical depressions in the Bay of Bengal during this period. According to data from the BMD, during the past 40 years, about 267 occurrences of depressions were recorded in the Bay of Bengal, with an average of 12.85 events per year. During this period, the average total duration of tropical depressions per year was 37.34 days. The occurrence of tropical depressions significantly varied in different months, although most depressions and cyclones were formed in October (58 observations) and November (52 observations). Furthermore, the longest durations of depressions were recorded in November (185 days), followed by October (167 days) and May (116 days) (Figure 3). According to the respondent fishers, the peak season of hilsa fishing is June to October. 


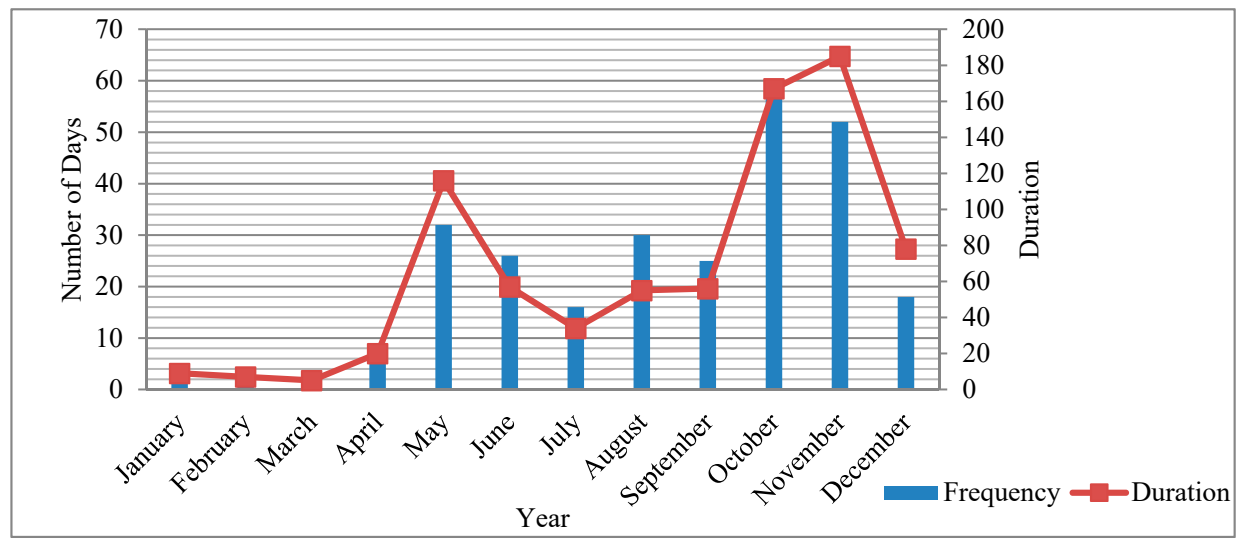

Figure 3. The total number of depression events (left side) and duration (right side) per month between 1975 and 2015 [51].

\subsection{Fishers' Perceptions of Vulnerability to Climate-Related Hazards}

Almost all of the respondents claimed to have experienced the variability and impacts of climate change during their fishing campaigns. In the last 10 years, they have faced more intense cyclones, more frequent storm surges and more substantial waves and ocean currents during fishing. The respondents also perceived variations in temperature and rainfall. According to the respondents, the risk of accidents during fishing in the Bay increased, their homestead land too more exposed to salt-water intrusion and flooding (Figure 4).

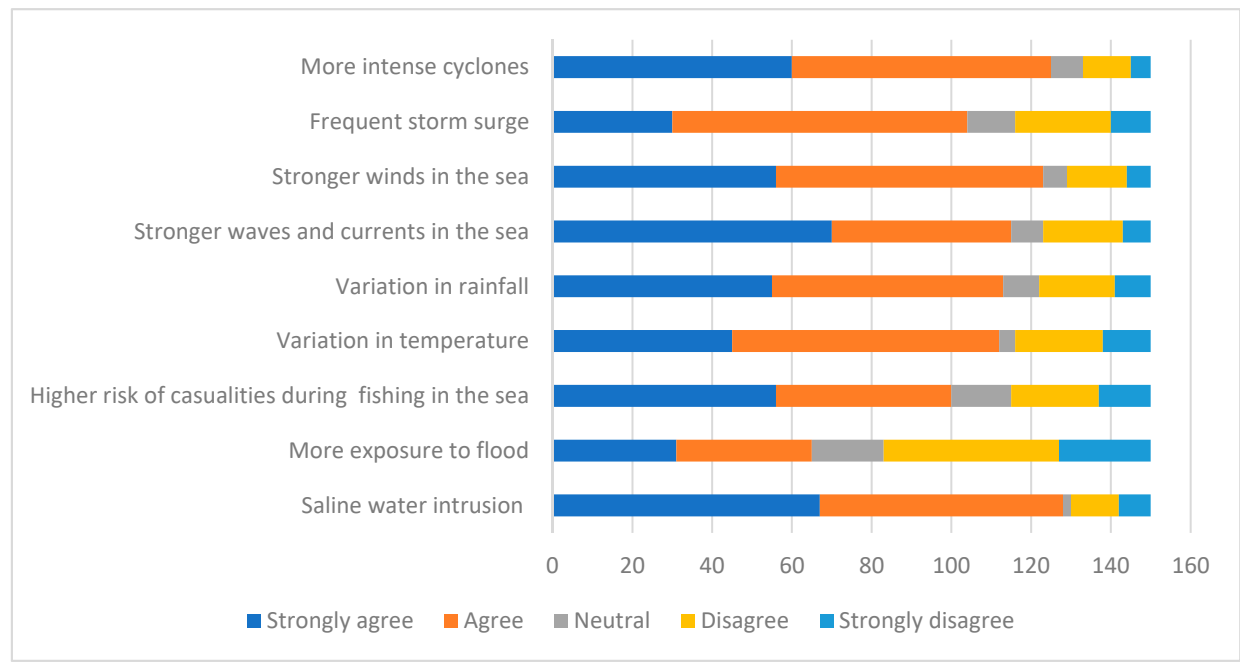

Figure 4. Fishers' perceptions of changes in climate-change induced events in the last 10 years.

\subsection{Fishers' Livelihood Assets and Climate Change Impacts}

\subsubsection{Human Capital}

The majority $(40.67 \%)$ of the fishers were illiterate and a similar percentage $(38.67 \%)$ have received up to five years of schooling (Table 3). Such widespread illiteracy is likely to limit their capacity for alternative livelihoods and overall resilience. Most of the fishers regarded fishing as a risky profession, exacerbated by increasingly rough weather conditions. Sadly, some of the fishers have lost colleagues due to death or because they have disappeared at sea. Many of the fishers have also suffered physical injuries due to extreme weather-related mishaps. The illness or physical inability of earning member(s) of the family are significant issues that may push families into poverty, often leading to family bankruptcy and worsening the health of other family members. According to one respondent 
from Fatapur, "During cyclone events, the surging water contaminates drinking water sources via sewage and salt water". Many fishers lack immediate access to medical facilities due to the remoteness of their location, yet their low health resistance may undermine their fishing activities and livelihoods. Most of the schools in the coastal area are designed and used as cyclone shelters during disaster events. As one key informant from Mahipur stated, the loss of educational materials, the unsuitability of schools for study and family crises all directly affect children's education.

Table 3. Summary of demography and livelihood capital.

\begin{tabular}{|c|c|c|}
\hline Criteria/Characteristics and a Brief Description & Parameters & \\
\hline \multicolumn{3}{|l|}{ Summary of Demographic Features } \\
\hline \multirow[t]{4}{*}{ Age $(\%)$} & $<18$ years & 10 \\
\hline & $18-40$ years & 71.33 \\
\hline & $41-50$ years & 10 \\
\hline & $>50$ years & 8.67 \\
\hline Average household member & 5.9 & \\
\hline \multicolumn{3}{|l|}{ Human Capital } \\
\hline \multirow[t]{4}{*}{ Education (\%) } & Illiterate & 40.67 \\
\hline & Primary & 38.67 \\
\hline & Secondary & 16.66 \\
\hline & Higher Secondary & 4 \\
\hline Access to health facilities (\%) & & 73 \\
\hline Year of fishing experiences & & 11.2 \\
\hline \multicolumn{3}{|l|}{ Natural Capital } \\
\hline Access to safe drinking water (\%) & & 93 \\
\hline Dependency on hilsa fishery (percentage of income) & & 86 \\
\hline Ownership of land (decimal) & & 0.92 \\
\hline \multicolumn{3}{|l|}{ Physical Capital } \\
\hline Live in own house (\%) & & 91 \\
\hline \multirow[t]{3}{*}{ Types of house (\%) } & $\begin{array}{c}\text { Kacha (floor with mud/clay and roof made of } \\
\text { natural materials (e.g., nypa palm leaves weaved } \\
\text { with bamboo slice) }\end{array}$ & 63.33 \\
\hline & Semi-pacca (cement floor and tin wall and roof) & 29.33 \\
\hline & Pacca (cement floor and iron sheet wall and roof) & 7.34 \\
\hline \multicolumn{3}{|l|}{ Access to toilet facilities (\%) } \\
\hline & Kacha (made of bamboo with leaves) & 52 \\
\hline & Semi-pacca (made of tin or wood, cement floor ) & 24 \\
\hline & $\begin{array}{l}\text { Pacca latrine (made of brick with cement and with } \\
\text { an effective drainage system). }\end{array}$ & 22.66 \\
\hline & Open place & 1.34 \\
\hline Access to electricity (\%) & & 79 \\
\hline \multirow[t]{3}{*}{ Social Capital } & Membership of organization (\%) & 76 \\
\hline & Receive support from a relative during crises (\%) & 83 \\
\hline & Receive assistance from the government (\%) & 77 \\
\hline \multicolumn{3}{|l|}{ Financial capital } \\
\hline Mean monthly income (Bangladeshi taka-BDT) & & $8524(3445)$ \\
\hline \multirow[t]{4}{*}{ Poverty status (self-assessment) (\%) } & Very poor & 7.34 \\
\hline & Poor & 59.34 \\
\hline & Middle income & 26.66 \\
\hline & Higher middle income & 6.66 \\
\hline
\end{tabular}




\subsubsection{Natural Capital}

Landlessness was said to be a significant issue among the respondent fishers ( 0.92 decimal), with a rate far higher than the national average. Many fishers live on or close to government-owned coastal embankment areas that form a protection wall against rising seawater (known as khas land). Most of the fishers have access to safe drinking water. Many households depend on natural resources in different ways, such as collecting fuel materials and grazing land for domestic animals. More importantly, the respondent fishers mostly depend on hilsa fisheries for a high percentage $(86 \%)$ of households income. Thus, the hilsa fisheries is considered as their most valuable natural asset. Most of the respondent fishers $(74 \%)$ agreed that hilsa fishery is subjected to ongoing environmental degradation in the region. One 60-year-old fisher from Hatempur said, "When we were young, we'd go out for an hour and come back with enough fish for a day. But now we go for eight hours, we go fishing deeper, fish further out, and still come up with less than half the fish compared to my younger days". The FGDs in the study sites revealed several anthropogenic factors, which they attributed to the degradation of hilsa fisheries in Bangladesh, including the building of upstream barrages and dykes, river pollution, destructive monofilament nets, fishing juveniles and brood species. Climate change was said to have accelerated this decline. The fishers mainly noted changes in terms of the availability of hilsa related to climatic variability.

\section{The Potential Impact of Climate Change on Various Stages of the Hilsa Life Cycle}

The larval stage is crucial in the hilsa life cycle. Inappropriate water quality harms the feeding and nursing of larvae, thus reducing larval growth. Moreover, ocean acidification and temperature change have also been shown to reduce fish larvae's ability to find a suitable habitat and to find their way home [52]. Thus, all of these changes are likely to affect the different life stages of the hilsa shad species (Figure 5).

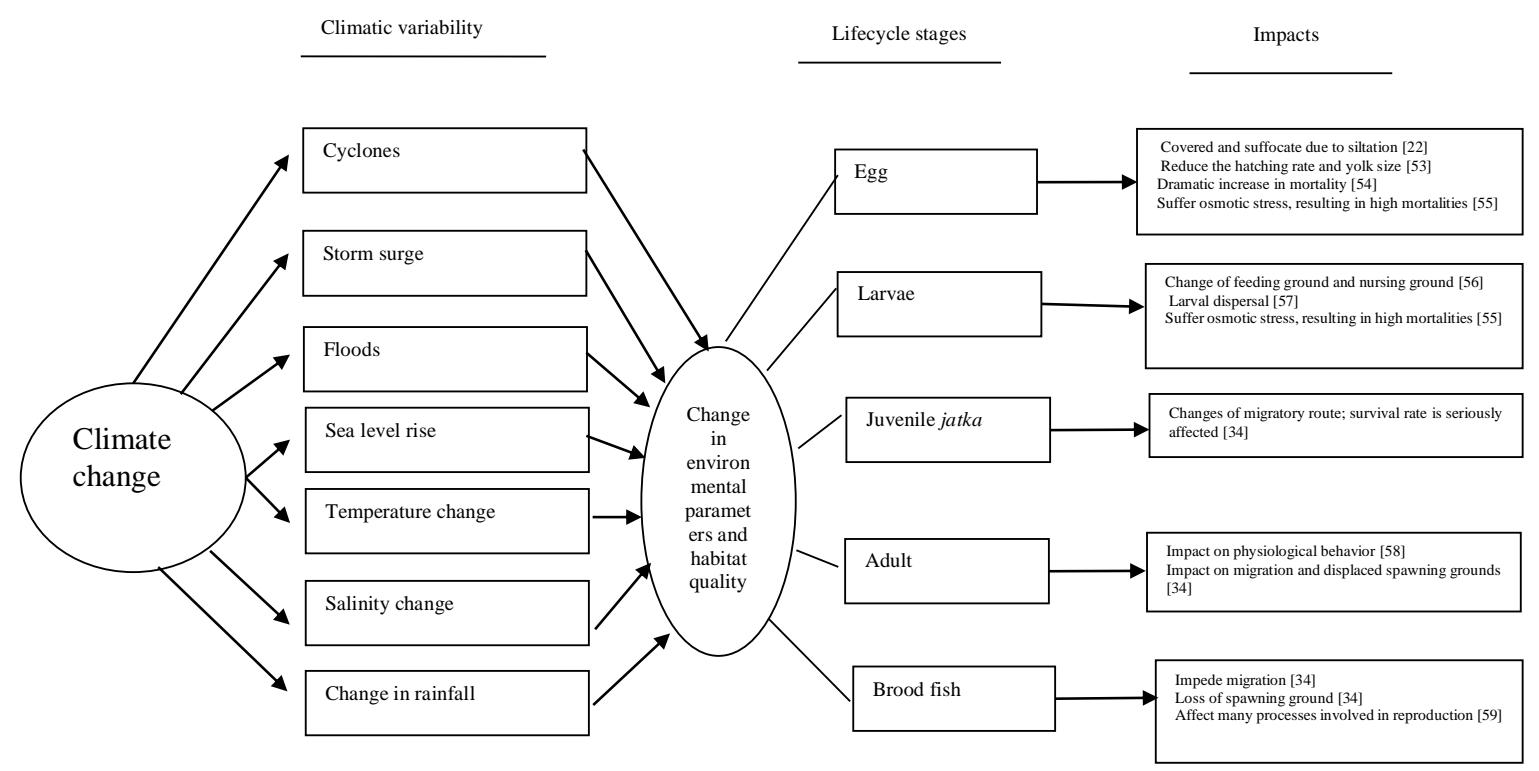

Figure 5. The potential impact of climate change on various stages of the hilsa life cycle [53-60].

Climatic variability affects the stock of the hilsa fishery. Increased sedimentation into riverbeds, changes to monsoon and rainfall patterns (rain is necessary for breeding) and changes in coastal morphology can all negatively affect the availability of hilsa species, as recognized by one key informant at the Department of Fisheries. This issue is particularly significant in the Bangladesh estuarine system. About 735 million metric tons of sediment have been estimated in the river systems every year, especially around the Hatia-Barisal-Patuakhali area, where the sediment is $18 \mathrm{~km}$ thick [60]. The high level of sedimentation $(>200-300 \mathrm{mg} / \mathrm{l}$ ) can cause fish mortality. Changes in water temperature are likely 
to affect the spatial and temporal distribution of spawning. Changes in spawning times, spawning areas and migratory behaviors are possible, with subsequent effects on stock sizes and fisheries [61]. As a key informant from the Department of Fisheries (DoF) claimed, "Due to sea level rise and salinity intrusion, hilsa have to migrate longer distances upstream to search for favorable water parameters, but on the other hand, upstream river discharge with heavy sediment loads constrains this migration by decreasing depth, creating submerged sandbars (dubochar)".

The fishers perceived that the migration routes of hilsa species have changed, so the production of hilsa species has decreased in areas where they were once abundant. Due to submerged sandbars along the coast and estuaries due to excessive siltation, the fish were assumed to have altered their course of movement from former breeding grounds. Furthermore, changes in rainfall patterns sometimes cause drought, which accelerates the impact of dryness and reduces water flow. Riverbed siltation is one of the most noteworthy causes of the diversion of hilsa migration routes. Brood hilsa need deep water, but now the river is becoming so heavy with silt that hilsa do not travel far upstream in rivers to do so, reducing their stock. As one fisher from Mahipur Bazar said, emotionally, "Where will you get fish in the river? Now the water in the river only reaches up to your knee, so no mature fish come to the river, only jatka".

\subsubsection{Physical Capital}

Fishers' physical capital include fishing equipment, boats, shelter, transportation, and road networks. Climatic extremities have a direct impact on physical assets. The hilsa fishers undertake fishing trips of various lengths, whether short-, medium-, or long-term (Table 4).

Table 4. Different types of fishing (based on FGDs in Char Gangamoti and Fatehpur).

\begin{tabular}{cccc}
\hline & \multicolumn{3}{c}{ Types of Fishing Campaigns } \\
\cline { 2 - 4 } & Short Duration & Medium Duration & Long Duration \\
\hline Fishing days & Daily fishing & $7-10$ days & 15 days or more \\
\hline Fishing boats & Small boat $(20 \mathrm{ft})$. & Medium boat $(22 \mathrm{ft})$. & Large boat $(30-55 \mathrm{ft})$. \\
\hline Engine power $(\mathrm{HP})$ & $20-22$ & $60-75$ & $100-110$ \\
\hline Manpower & $2-5$ & $10-15$ & $10-20$ \\
\hline Fishing gear & Gillnet & Gillnet & Gillnet \\
\hline Fishing area & Inshore & Offshore & Deep seawater \\
\hline Target species & Hilsa, jewfish, shrimp & Hilsa, pomfret & Hilsa \\
\hline
\end{tabular}

Fishers must invest a large amount of money for any kind of trip, with significant costs involved in boats, engines, fishing gear and maintenance. Any natural calamity in the sea causes damage or a loss of fishing equipment, especially boats and nets. One fisher from Char Gangamoti said, "To save ourselves from the strong winds and storm surges of cyclones we have to return to the shore quickly, leaving our fishing gear on the water. Sometimes we must return to the shore without any catch. Thus, we face financial losses from incomplete trips".

Most fishers live close to the coast or a river for easy access to a water body, exposing them to waterborne disasters that may cause severe damage to their villages' already weak and fragile infrastructure. Most households (63.33\%) live in houses made of mud and leaves, which can be easily destroyed by wind or tidal surges. Respondents stressed that when a cyclone strikes, coastal dams and other infrastructure wash away. Thus, villages are either waterlogged or inundated by the high water flow of the daily tide. Loss of house and homestead land due to river or coastal erosion are driving forces that push many fishers to migrate. One victim of the devastating Cyclone Sidr in 2007 from Hatempur said, "After getting warnings, we stopped fishing and went back to a nearby cyclone shelter, putting down fishing nets in the sea. I was unable to communicate with my family. The next 
day, when I came home, I saw nobody in my destroyed house. I lost my two cows and four goats. Although I found most of my family members in a nearby shelter, unfortunately we are still waiting for my missing younger brother". Due to increased salinity and reduced subsoil water level, drinking water is a general concern in coastal areas in Bangladesh. Most of the respondents (52\%) claimed to use kacha latrines (made of bamboo with leaves), 24\% use semi-pacca (made of tin or wood), and $22.66 \%$ use pacca latrines (made of brick with cement and with an effective drainage system), while $1.34 \%$ claimed not to have a sanitary facility and to instead use open places (Table 3).

\subsubsection{Social Capital}

By working as a group while fishing in the Bay, most of the fishers claimed to feel a strong form of social bonding. The findings of the FGDs revealed that in the immediate aftermath of a disaster, poor coastal fishers initially try to survive by drawing support from social connections, such as help from neighbors or nearby relatives. However, with the increasing intensity and occurrence of climate-induced extreme events, social cohesion alone is inadequate for disaster preparedness and livelihood recovery. Increasing the number of hard-core poor and widening income inequality among fishing communities creates social envy, opportunism, and conflicts of interest (FGDs in Fatapur). Rehabilitation and relief programs after any disaster also create disputes between beneficiaries and non-beneficiaries. Consequently, tensions may rise among fishers, loosening social bonding. Information gathered from the FGDs revealed that genuine fishers are sometimes may deprived of relief due to nepotism and bias related to partisan politics.

\subsubsection{Financial Capital}

The monthly income of the hilsa fishers was found to average 8524 BDT ( USD 100). Therefore, the overall socioeconomic conditions of the hilsa fisher folk are deplorable. Moreover, suppose that production declines, the socioeconomic conditions of the hilsa fishers will worsen further. One fisher from Fatapur said, "The hilsa are disappearing in our fishing area, and we have to travel long distances in the sea to chase fish, requiring more fuel and investment". The majority of the fishers (60\%) claimed to have no secondary occupation, with fishing, thus, their sole income source. The peak availability of hilsa was said to be from June to October. However, even in the peak-fishing season, hilsa fishing is hampered by recurrent depression and cyclone events in the Bay. The fishers' groups invest lots of money for a single fishing trip. Most of these groups take credit (locally known as dadon) from moneylenders or microcredit from NGOs at high interest rates for each fishing trip's operating costs. Following the issuance of disaster warnings, fishers in the Bay are forced to return to the shore without completing their fishing trips, leading to economic hardship, and putting a strain on their livelihoods, especially in the peak fishing period. Based on the calculations of the FGD in Char Gangamoti, before considering boats and nets, one incomplete trip costs a minimum of BDT 76,400 ( 900 USD) for miscellaneous expenses such as fuel, ice, and groceries. Many fishers have lost their boats and fishing gear due to turbulent weather conditions. This can put fishers into double problems; firstly, they cannot re-arrange their nets for fishing; secondly, their previous credit and debt burden puts them in critical social and economic conditions [20], ultimately forcing them into a poverty trap [31]. As one boat owner from Mahipur said, “During Cyclone Sidr, my two fishing trawlers were destroyed. I took BDT 50,000 ( 590 USD) as a loan with a one-year duration to reconstruct a boat, and I have to pay 500 taka per month as interest. Still, due to the turbulent weather this year, the income is not so good".

\subsection{Livelihood Strategies to Deal with the Impacts of Climatic Variability Concerning Capital}

Cyclones and tropical depressions were the most cited extreme events that profoundly affect the respondent fishers' livelihood assets. Most of the fishers receive cautionary signal warnings of a severe cyclone. After receiving a rough weather signal, many of them return close to the shore and continue fishing, but return home if the situation worsens. However, in some cases, fishers may fail to return to the shore swiftly and so they must stop fishing and keep their boat in a specific position considering 
the wind direction and force. They then tie their net floats together tightly and keep plastic bottles or drums beside them for safety. In severe conditions, they may choose to throw their fishing gear into the sea to keep their boat lighter against strong waves and stay in the boat. To overcome losses and damage caused by a disaster, most of the respondents quickly return to fishing as an immediate coping strategy (Table 5).

Table 5. Fisher livelihood strategies to deal with the impacts of climatic variability concerning livelihood assets.

\begin{tabular}{|c|c|c|c|c|}
\hline \multirow{2}{*}{$\begin{array}{l}\text { Livelihoods } \\
\text { Assets }\end{array}$} & \multicolumn{2}{|c|}{ Short-Term Strategies } & \multirow{2}{*}{ Long-Term Strategies } & \multirow{2}{*}{ Livelihood Outcomes } \\
\hline & Before an Extreme Event & After an Extreme Event & & \\
\hline \multirow[t]{2}{*}{ Natural } & $\begin{array}{l}\text { End fishing campaign and } \\
\text { return to shore }\end{array}$ & $\begin{array}{l}\text { Immediately return to } \\
\text { fishing }\end{array}$ & Increased fishing efforts & $\begin{array}{l}\text { Food security and income } \\
\text { security }\end{array}$ \\
\hline & $\begin{array}{l}\text { Tighten the house with a } \\
\text { rope around a tree }\end{array}$ & & Tree plantation around home & \\
\hline \multirow[t]{2}{*}{ Physical } & $\begin{array}{l}\text { Bring boat and fishing gear } \\
\text { to a safer place }\end{array}$ & $\begin{array}{l}\text { Re-construct house with } \\
\text { local materials }\end{array}$ & $\begin{array}{l}\text { Construct house on a higher } \\
\text { plinth and with concrete }\end{array}$ & $\begin{array}{l}\text { Asset accumulation (house, } \\
\text { fishing gear including } \\
\text { boats and fishing nets) }\end{array}$ \\
\hline & $\begin{array}{l}\text { Store valuable physical } \\
\text { assets in a safe place }\end{array}$ & $\begin{array}{l}\text { Reconstruct fishing gear } \\
\text { to start fishing }\end{array}$ & $\begin{array}{l}\text { Migrate to a more secure } \\
\text { place }\end{array}$ & \\
\hline \multirow[t]{4}{*}{ Human } & $\begin{array}{l}\text { Take shelter in a cyclone } \\
\text { center }\end{array}$ & $\begin{array}{l}\text { Treat injured family } \\
\text { members }\end{array}$ & $\begin{array}{l}\text { Better education for capacity } \\
\text { building to find a safer } \\
\text { occupation }\end{array}$ & $\begin{array}{l}\text { Well-being and high status } \\
\text { in the community/poverty } \\
\text { reduction }\end{array}$ \\
\hline & $\begin{array}{l}\text { Take shelter in } \\
\text { neighboring house built } \\
\text { from concrete materials }\end{array}$ & $\begin{array}{l}\text { Remove children from } \\
\text { school to reduce family } \\
\text { costs }\end{array}$ & $\begin{array}{l}\text { Migrate to a safer location } \\
\text { with higher income }\end{array}$ & \\
\hline & & Send children to work & Leave the fishing profession & \\
\hline & & Reduce food intake & & \\
\hline Social & $\begin{array}{l}\text { Communicate and relay } \\
\text { disaster messages and } \\
\text { information }\end{array}$ & $\begin{array}{l}\text { Communicate with peers } \\
\text { for comfort and } \\
\text { psychological support }\end{array}$ & & Social bonding \\
\hline \multirow[t]{4}{*}{ Financial } & $\begin{array}{l}\text { Buy necessary groceries. } \\
\text { Borrow essential groceries } \\
\text { from relatives }\end{array}$ & $\begin{array}{l}\text { Liquidate personal } \\
\text { savings and assets }\end{array}$ & $\begin{array}{c}\text { Take alternative } \\
\text { income-generating activities, } \\
\text { particularly by other family } \\
\text { members }\end{array}$ & $\begin{array}{c}\text { Changes in well-being and } \\
\text { poverty status }\end{array}$ \\
\hline & & $\begin{array}{l}\text { Taking a loan from a } \\
\text { moneylender }\end{array}$ & $\begin{array}{l}\text { Adopt saving strategies, } \\
\text { particularly by women }\end{array}$ & \\
\hline & & $\begin{array}{l}\text { Relief from government } \\
\text { and NGOs }\end{array}$ & & \\
\hline & & Reduce expenditures & Migration & \\
\hline
\end{tabular}

Fishers also adopt different land strategies, such as going to a cyclone shelter or a neighbor's or relative's house during a cyclone event. However, before doing so, they manage their household assets. They move to a cyclone shelter with valuable assets and dry food. Some fishers stay at home and take precautionary measures. Most of them receive direct or indirect support from their relatives during adverse conditions. Due to unfortunate financial situations, they tend to reduce their expenditures (97\%) and food intake (75\%). Many of them (56\%) stop their children's education and send them to work. Fishers may also sell their livestock and physical assets to support the family.

Moreover, due to mass destruction and a lack of alternative income sources, many fishers $(69 \%)$ migrate to another area, changing their profession. Relief from the government and NGOs and loans from moneylenders/fishery entrepreneurs often help them to restart their livelihoods. The rehabilitation of damaged structures is also supported by the government, i.e., financial, physical, and instrumental assistance. However, as regards relief distribution, some fishers complained about favoritism, and conflicts that compromise their resilience. Some fishers also migrate to find a safer place and a better income.

In the case of long-term strategies, some fishers said that to compensate for the losses caused by disaster events, they often increase their fishing efforts. In such cases, fishers often use illegal 
monofilament gill nets. One fisher from Char Kukri Mukri said that "Due to heavy siltation in the estuary, the current water has slowed down, so traditional gears do not catch much fish, hence many fishers use monofilament gill nets to indiscriminately catch all size and species". Wealthier coastal fishers may also plant trees around their house, or build it on a higher plinth and use concrete. Many fishers shift their homes further inland. Some fishermen foresaw a better future for their children and thus invested in education so that they could find a safer occupation. Women in fishing households are also actively involved in alternative occupations that occasionally help them put aside some savings for crisis periods. Both temporary and permanent migration was also noted by the fishers. However, many of the fishers claimed to want to continue fishing. As one fisherman from Mahipur explained, "A fisherman is always a fisherman; fish are in our thoughts; fish are our dreams; a fishy smell comes from our skin; fish are in our every discussion. We are gambling for fish throughout life; we are crazy for fish". This saying indicates a secure attachment to their profession and place.

\subsection{Institutional Capacity and Responses}

The majority ( $84 \%$ ) of the fishers claimed to receive messages of cautionary weather signals, mainly by radio or short message service (SMS). Cyclone shelters constitute the most critical government-supported facility for cyclone-affected communities during adverse climatic conditions. Slightly less than eighty percent (77\%) of the respondents claimed to have a cyclone center under $2 \mathrm{~km}$ away. Union Parishad is the lowest tier of the local government, from which $71 \%$ of the respondents have received support, mainly relief materials after a cyclonic disaster. Along with the government, various national and international non-government organizations come forwards to help victims after a disaster. However, immediate access to health services is weak, as only $39 \%$ of the respondents agreed that they had access to the government facilities they required during a previous disaster (Table 6). Few key informants reported the remoteness of their locations or higher demand for rush services as the primary reasons for poor health services during a disaster.

Table 6. Fishers' access to various services during tropical cyclone events (multiple answers).

\begin{tabular}{ccc}
\hline Institutions and Services & Description & Percentage \\
\hline Cyclone shelter & $\begin{array}{c}\text { If the respondent has access to a cyclone shelter within } \\
2 \mathrm{~km} \text { distance during adverse climatic conditions }\end{array}$ & 77 \\
\hline $\begin{array}{c}\text { Local government administration } \\
\text { (Union Parishad) }\end{array}$ & $\begin{array}{c}\text { If the respondent receives support during the response } \\
\text { to an extreme climatic event }\end{array}$ & 71 \\
\hline Fishers' organization & $\begin{array}{c}\text { If the respondent receives help from own organization } \\
\text { during adverse climatic conditions }\end{array}$ & 44 \\
\hline Cautionary weather signal & $\begin{array}{c}\text { If the respondent receives appropriate information } \\
\text { during adverse climatic conditions }\end{array}$ & 84 \\
\hline Support from NGOs & $\begin{array}{c}\text { If the respondent receives support from NGOs during } \\
\text { adverse climatic conditions }\end{array}$ & 62 \\
\hline Access to health services & $\begin{array}{c}\text { If the respondent has access to proper health services } \\
\text { during adverse climatic conditions }\end{array}$ & 39 \\
\hline
\end{tabular}

The FGDs revealed that many of the respondents have also received some training and have participated in an awareness-building program organized by the Department of Fisheries about using protective safety measures while fishing in the sea. The Bangladesh government has also arranged a compensation scheme for any fisher who dies while fishing in the Bay, whereby the deceased fisher's family receives BDT 50,000 ( 590 USD). Furthermore, the FGDs in Char Kukri Mukri revealed that the coastal afforestation program of the Department of Forest has substantially reduced the risks associated with high-intensity cyclones through creating a bio-shield. 


\subsection{Resulting Systemic Vulnerabilities and Recommendations for Better Livelihood Outcomes}

The present study's findings confirm that Bangladesh's coastal fisheries sector is exposed to environmental hazards and is vulnerable to projected climatic variability. Climatic shocks and trends are increasing gradually, with detrimental implications for fishers' primary target species, hilsa. The unpredictable patterns of extreme events also take a toll on fishers' safety. Such coastal small-scale fishers in Bangladesh face a double problem [21]. The hilsa shad species are vulnerable to climate change's impacts. Changing climatic variables will profoundly alter the effects of environmental conditions (e.g., temperature, water flow, rainfall, availability of nutrients) on biological and ecological processes and the sensitivities of species in the niche [62]. These changes are particularly profound in tropical fisheries and habitats [14]. Climate change impacts will be further compounded by other anthropogenic threats such as over-exploitation, environmental pollution, or habitat degradation. These stresses will erode the resilience of the ecosystem to fight against climate change. This case is particularly evident in the case of hilsa fisheries. Hilsa shad (Tenualosa ilisha) is a highly migratory and anadromous fish that shares similar migratory and breeding behaviors as Atlantic salmon (Salmo sp.). Various anthropogenic disturbances, such as increased siltation and rising riverbeds, have disrupted or even destroyed the migratory routes and spawning grounds of hilsa over time. Consequently, over the last twenty years, hilsa production from inland waters has declined by about $20 \%$, whereas the marine water yield has increased nearly three times [34]. This indicates that the significant hilsa ground has gradually shifted from inland to marine waters. Many experts believe that different oceanographic changes, namely high turbidity, increased flooding, tidal action and salinity changes, have accelerated the shift in hilsa migration patterns of spawning, growth and production [34]. As a direct consequence of this shift, fishers must travel long distances or from estuarine and marine waters for their catch. This involves risks, in terms of both increased fuel and time, and facing more stormy weather conditions that may lead to casualties.

Environmental risks related to climate change are likely to aggravate economic hardship in coastal fisheries of Bangladesh [19]. Small-scale coastal fishers are more vulnerable than any other professional group. They depend on climate-sensitive hilsa fisheries for the majority of their income. Such dependency on a single species may lead to a risk of livelihood failure if the stock collapses. Given their generally strong attachment to their place and occupation and their limited skill set for alternative occupations, the scenario appears particularly severe for small-scale fisheries. The present study's findings confirm that vulnerability is context-specific and that small-scale coastal fishers are especially vulnerable due to their socio-ecological context, hence, they deserve more attention. Although the legal and policy frameworks related to climate change and disaster risk reduction in Bangladesh have several provisions related to increasing focus on vulnerable populations (Table 7), coastal fishing communities have tended to be regarded as a broader part of coastal communities, with very little attention paid by the government to small-scale fisheries. Even though many NGOs are working in Bangladesh, very few of them consider small-scale fisheries-related issues. Thus, a lack of institutions targeting coastal and marine fisheries is apparent [33]. This disadvantaged situation needs to be changed, considering the vulnerability of many fishing populations and the social and economic contribution of fisheries to the national economy.

The small-scale fisher's group are one of the most vulnerable groups exposed to disaster risks and climate change impacts. Thus, the SSF Guidelines (which was endorsed by the Food and Agricultural Organizations of the United nations) [42] are an appropriate and timely instrument for initiating policy change to make small-scale fisheries more resilient [4]. 
Table 7. Legal, policy and institutional frameworks to climate change responses of small-scale fishers in Bangladesh (modified from [33]).



The SSF guidelines rightly mention and state the different vulnerabilities of various sectors for small-scale fisheries and develop specific policies and plans. The guidelines also address climate change adaptation, mitigation, emergency response, and disaster preparedness through consultation with local fishing communities. These adaptations and policies can be steered effectively in societal responses for sustaining small-scale fisheries [14]. Considering the ecological perspective, the riverine habitats and migration routes of hilsa should be rehabilitated by dredging silted river channels to improve and sustain the river flow and riverine ecosystem. Another set of required actions is natural de-siltation (tree plantation) in order to prevent siltation and improve the flow of the rivers and their tributaries. The indiscriminate discharge of various wastes, chemicals, and industrial effluents into aquatic habitats must be regulated to control rivers, estuaries and seas [29]. In addition, to cease 
siltation in natural river de-siltation, tree plantation should be adopted. These efforts may help in 'building back better' small-scale fisheries as stipulated in the SSF Guidelines. Climate change risks are affecting small-scale fisheries in Bangladesh at different spatial and temporal scales. Thus, in line with the SSF Guidelines, an integrated and holistic approach that includes cross-sectoral collaboration is required. In the present study, different human-induced, non-fisheries-related factors like pollution, coastal erosion, and destruction of coastal habitats have been found to undermine fishing communities' livelihoods. These communities' abilities to adapt to the possible impacts of climate change need to be increased. Ecosystem-based fisheries management will be the right step forward.

In terms of post-disaster intervention, short-term loss and damage tend to draw the attention of policy makers and donor agencies, while the long-term residual impacts of extreme events receive less attention [33]. However, effective anticipation and knowledge are required to reduce future losses and damage [33]. To achieve this objective, long-term development strategies are required throughout the emergency sequence, including in the immediate relief phase, rehabilitation, and reconstruction. Furthermore, a recovery measure should include reducing vulnerabilities to potential future threats. The concept of 'building back better' should be applied in disaster response and rehabilitation (SSF Guidelines, para. 9.7) [42]. Security in offshore fishing needs to be ensured through accurate and timely warning systems and lifesaving opportunities onboard. Moreover, on land, fishing settlements need to be further protected through concrete embankments and a mangrove bio-shield. For this existing artificial mangrove, plantation should be strengthened to protect the land from siltation and to reduce the intensity of strong winds. Ensuring easy access to and safety in cyclone shelters alongside the expansion of necessary facilities should be other priorities. To ensure long-term resilience and well-being, essential civic facilities, such as access to safe drinking water, sanitation, and community medical facilities should also be provided. This might be achieved through small-scale fishing communities' transparent access to adaptation funds, facilities, and culturally appropriate technologies (SSF Guidelines para. 9.9) [42].

\section{Conclusions}

The present study was undertaken to assess the impacts of climate change on the hilsa fishery system and the adaptive measures taken by fisher communities in Bangladesh's coastal region. The study found that climate change has enormous adverse effects on the country's most impoverished fishing communities by affecting their livelihood assets, specifically by reducing the hilsa stock upon which their livelihoods are based. Climate change has potential impacts on the life cycle stages and migration patterns of hilsa. Furthermore, damage to physical assets, fishing equipment, houses, and infrastructure, for instance, intensify these communities' vulnerability. In the coming decades, the vulnerability of hilsa fishers' livelihoods may substantially increase because of climate change. Heavy dependence on climate-vulnerable hilsa shad species risk the livelihood failure of fishers if the stock collapses. Such changes in fish production and subsequent impacts on fishery-based livelihoods will have significant implications for achieving the UN Sustainable Development Goals [14]. Based on this study's findings, it is essential to ensure increased hilsa production through limiting anthropogenic causes because fishers' livelihoods are based on it. Providing a suitable environment and conservation of hilsa is necessary. Security in deep sea fishing was said to be the highest priority of hilsa fishers. The modernization of fishing technology (such as higher quality fishing boats) and radio signaling may help save lives reduce damage to fishing assets, particularly from cyclones. Possible initiatives need to be undertaken to protect physical infrastructure. Priority should be given to constructing cyclone shelters at a reasonable distance from the sea and with adequate facilities. The government and/or NGOs should support or provide an alternative source of income-generating opportunities for coastal fishing communities when they have no work available in order to reduce their livelihood vulnerability. It is also vital to make a list of actual victims to support them properly. Access to less expensive financial credit through institutional reform may help to transform fishing, build human capital, facilitate necessary migration, and assist the diversification of livelihoods. The SSF 
Guidelines have important provisions on making small-scale fishers more resilient. This article has mainly focused on households and the community scale. Although this research attended to both fish and fishers, more intensive research is needed to analyze the impacts of climate change on hilsa fish biology. A further study might consider fishers' performances toward alternative livelihoods.

Author Contributions: M.M.I. conceptualization, analysis, draft preparation, editing; N.I. fieldwork, analysis, draft preparation; A.H. review, editing; M.M.H.M. review, editing. All authors have read and approved the final version. All authors have read and agreed to the published version of the manuscript.

Funding: This research was funded by “Too Big To Ignore: Global Partnership for Small-Scale Fisheries Research" funded by the Social Sciences and Humanities Research Council of Canada (grant number 895-2011- 1011). The APC was funded by University Malaysia Terengganu.

Acknowledgments: We acknowledge the respondents who participated in this study. We thank the two anonymous reviewers for their very useful comments and suggestions.

Conflicts of Interest: The authors declare no conflict of interest.

\section{References}

1. Pandit, S.N.; Maitland, B.M.; Pandit, L.K.; Poesch, M.S.; Enders, E.C. Climate change risks, extinction debt, and conservation implications for a threatened freshwater fish: Carmine shiner (Notropis percobromus). Sci. Total Environ. 2017, 598, 1-11. [CrossRef] [PubMed]

2. Leadley, P.; Pereira, H.M.; Alkemade, R.; Fernandez-Manjarre's, J.F.; Proenca, V.; Scharleman, J.P.W. Biodiversity Scenarios: Projections of 21st Century Change in Biodiversity and Associated Ecosystem Services. Technical. Montreal: Secretariat of the Convention on Biological Diversity. 2010. Available online: https://www.cbd.int/doc/publications/cbd-ts-50-en.pdf (accessed on 21 August 2020).

3. Pachauri, R.; Allen, M.; Barros, V.; Broome, J.; Cramer, W.; Christ, R.; Dubash, N.K. Climate Change; Synthesis Report; Contribution of Working Groups I, II and III to the Fifth Assessment Report of the Intergovernmental Panel on Climate Change; IPCC: Geneva, Switzerland, 2014; p. 151.

4. FAO. Climate Change Implications for Fisheries and Aquaculture. Summary of the Findings of the Intergovernmental Panel on Climate Change Fifth Assessment Report. 2016. Available online: http: //www.fao.org/3/a-i5707e.pdf (accessed on 22 August 2020).

5. Pecl, G.T.; Araújo, M.B.; Bell, J.D.; Blanchard, J.; Bonebrake, T.C.; Chen, I.-C.; Clark, T.D.; Colwell, R.K.; Danielsen, F.; Evengård, B. Biodiversity Redistribution under Climate Change: Impacts on Ecosystems and Human Well-Being. Science 2017, 355, 6332. [CrossRef] [PubMed]

6. Brander, K. Impacts of climate change on fisheries. J. Mar. Syst. 2010, 79, 389-402. [CrossRef]

7. Coulthard, S. Adaptation and conflict within fisheries: Insights for living with climate change. In Adapting to Climate Change: Thresholds, Values, Governance; Adger, W., Lorenzoni, I., O'Brien, K., Eds.; Cambridge University Press: Cambridge, UK, 2009; pp. 255-268.

8. Mendenhall, E.; Hendrix, C.; Nyman, E.; Roberts, P.M.; Hoopes, J.R.; Watson, J.R.; Lam, V.W.; Sumaila, U.R. Climate change increases the risk of fisheries conflict. Mar. Policy. 2020, 117, 103954. [CrossRef]

9. Haas, B.; Fleming, A.; McGee, J.; Haward, M. Regional fisheries organizations and sustainable development goals 13 and 14: Insights from stakeholders. Fish. Res. 2020, 226, 105529. [CrossRef]

10. Koenigstein, S.; Mark, F.C.; Gößling-Reisemann, S.; Reuter, H.; Poertner, H.O. Modelling climate change impacts on marine fish populations: Process-based integration of ocean warming, acidification and other environmental drivers. Fish Fish. 2016, 17, 972-1004. [CrossRef]

11. Cinner, J.E.; Adger, W.N.; Allison, E.H.; Barnes, M.L.; Brown, K.; Cohen, P.J.; Gelcich, S.; Hicks, C.C.; Hughes, T.P.; Lau, J. Building adaptive capacity to climate change in tropical coastal communities. Nat. Clim. Chang. 2018, 8, 117-123. [CrossRef]

12. Barange, M.; Bahri, T.; Beveridge, M.C.; Cochrane, K.L.; Funge-Smith, S.; Poulain, F. Impacts of Climate Change on Fisheries and Aquaculture: Synthesis of Currrent Knowledge, Adaptation and Mitigation Options; FAO: Rome, Italy, 2019.

13. Islam, M.M.; Sallu, S.; Hubacek, K.; Paavola, J. Vulnerability of fishery-based livelihoods to the impacts of climate variability and change: Insights from coastal Bangladesh. Reg. Environ. Chang. 2014, 14, 281-294. [CrossRef] 
14. Lam, V.W.; Allison, E.H.; Bell, J.D.; Blythe, J.; Cheung, W.W.; Frölicher, T.L.; Gasalla, M.A.; Sumaila, U.R. Climate change, tropical fisheries and prospects for sustainable development. Nat. Rev. Earth Environ. 2020, 1-15. [CrossRef]

15. Blasiak, R.; Spijkers, J.; Tokunaga, K.; Pittman, J.; Yagi, N.; Österblom, H. Climate change and marine fisheries: Least developed countries top global index of vulnerability. PLOS ONE 2017, 12, e0179632. [CrossRef]

16. SMRC. The Vulnerability Assessment of the SAARC Coastal Region due to Sea Level Rise: Bangladesh Case; SAARC Meteorological Research Council (SMRC): Dhaka, Bangladesh, 2003.

17. Unnikrishnan, A.S.; Kumar, K.R.; Fernandes, S.E.; Michael, G.S.; Patwardhan, S.K. Sea level changes along the Indian coast: Observations and projections. Curr. Sci. 2006, 90, 362-368.

18. Ali, A.; Chowdhury, J.U. Tropical cyclone risk assessment with special reference to Bangladesh. Mausam 1997, 48, 22.

19. Habib, A. Possible Economic Impact on Coastal Fish Stock Resources in Bangladesh in the Case of Climate Change. Master's Thesis, University of Tromso, Tromso, Norway, 2010.

20. Chowdhury, S.R.; Hossain, M.S.; Shamsuddoha, M.; Khan, S.M.M.H. Coastal Fishers' Livelihood in Peril: Sea Surface Temperature and Tropical Cyclones in Bangladesh; Center for Participatory Research and Development: Dhaka, Bangladesh, 2012.

21. Rawlani, A.K.; Sovacool, B.K. Building responsiveness to climate change through community based adaptation in Bangladesh. Mitig. Adapt. Strat. Glob. Chang. 2011, 16, 845-863. [CrossRef]

22. Jahan, I.; Ahsan, D.; Farque, M.H. Fishers' local knowledge on impact of climate change and anthropogenic interferences on Hilsa fishery in South Asia: Evidence from Bangladesh. Environ. Dev. Sustain. 2017, 19, 461-478. [CrossRef]

23. Daw, T.; Adger, W.N.; Brown, K.; Badjeck, M.C. Climate Change and Capture Fisheries: Potential Impacts, Adaptation and Mitigation; FAO Fisheries and Aquaculture Technical Paper: Rome, Italy, 2009; pp. 107-150. Available online: https://digitalarchive.worldfishcenter.org/bitstream/handle/20.500.12348/1339/WF_2545. pdf?sequence=1 (accessed on 25 February 2020).

24. Khattabi, A.; Jobbins, G. Vulnerability and adaption of traditional fisheries to climate change. In World Small-Scale Fisheries: Contemporary Visions; Chuenpagee, R., Ed.; Eburon Academic Publishers: Delft, The Netherlands, 2011; pp. 63-80.

25. Wahab, M.A.; Phillips, M.J.; Mohammed, E.Y. Payments for Hilsa fish (Tenualosa ilisha) conservation in Bangladesh. In Economic Incentives for Marine and Coastal Conservation: Prospects, Challenges and Policy Implications; Mohammed, E.Y., Ed.; Routledge: New York, NY, USA, 2014; pp. 170-189.

26. Halder, G.C. Present Status of the Hilsa Fishey in Bangladesh; Completion Report of the Studies Conducted under the ARDMCS, GEF Component and FFP; Department of Fisheries: Dhaka, Bangladesh, 2004.

27. Hossain, M.S.; Sarker, S.; Chowdhury, S.R.; Sharifuzzaman, S.M. Discovering spawning ground of Hilsa shad (Tenualosa ilisha) in the coastal waters of Bangladesh. Ecol. Model. 2014, 282, 59-68. [CrossRef]

28. Quddus, M.M.; Shimizu, A.M.; Nose, Y. Comparison of age and growth of two types of Hilsa in Bangladesh waters. Bull. Jpn. Soc. Sci. Fish. 1984, 13, 87-93. [CrossRef]

29. Hossain, M.A.; Das, I.; Genevier, L.; Hazra, S.; Rahman, M.; Barange, M.; Fernandes, J.A. Biology and fisheries of Hilsa shad in Bay of Bengal. Sci. Total Environ. 2019, 651, 1720-1734. [CrossRef]

30. DoF. Yearbook of Fisheries Statistics of Bangladesh; Fisheries Resources Survey System (FRSS), Department of Fisheries, Ministry of Fisheries: Dhaka, Bangladesh, 2018; Volume 35, p. 129.

31. Islam, M.M. Living on the margin: The poverty-vulnerability nexus in the small-scale fisheries of Bangladesh. In Poverty Mosaics: Realities and Prospects in Small-Scale Fisheries; Springer: Dordrecht, The Netherlands, 2011; pp. 71-95.

32. Fernandes, J.A.; Kay, S.; Hossain, M.A.; Ahmed, M.; Cheung, W.W.; Lazar, A.N.; Barange, M. Projecting marine fish production and catch potential in Bangladesh in the 21st century under long-term environmental change and management scenarios. ICES J. Mar. Sci. 2016, 73, 1357-1369. [CrossRef]

33. Islam, M.M.; Jentoft, S. Addressing disaster risks and climate change in coastal Bangladesh: Using the Small-Scale Fisheries Guidelines. In The Small-Scale Fisheries Guidelines; Springer: Cham, Switzerland, 2017; pp. 521-539.

34. Miah, M.S. Climatic and anthropogenic factors changing spawning pattern and production zone of Hilsa fishery in the Bay of Bengal. Weather. Clim. Extremes. 2015, 7, 109-115. [CrossRef] 
35. Chambers, R.; Conway, G. Sustainable Rural Livelihoods: Practical Concepts for the 21st Century; Institute of Development Studies: Brighton, UK, 1992.

36. Ellis, F. Rural Livelihoods and Diversity in Developing Countries; Oxford University Press: New York, NY, USA, 2000.

37. Allison, E.H.; Ellis, F. The livelihoods approach and management of small-scale fisheries. Mar. Policy. 2001, 25, 377-388. [CrossRef]

38. Carney, D. Sustainable livelihoods. In Sustainable Rural Livelihoods: What Contribution Can We Make; Department for International Development: London, UK, 1998; Volume 3, p. 27.

39. Hammill, A.; Leclerc, L.; Myatt-Hirvonen, O.; Salinas, Z. Using the sustainable livelihoods approach to reduce vulnerability to climate change. In Tropical Forests and Adaptation to Climate Change; Center for International Forestry Research: Bogor, Indonesia, 2005; pp. 71-96.

40. Eakin, H.; Luers, A.L. Assessing the vulnerability of social-environmental systems. Annu. Rev. Environ. Resour. 2006, 31, 365-394. [CrossRef]

41. FAO. The State of World Fisheries and Aquaculture Sustainability in Action; FAO: Rome, 2020. [CrossRef]

42. FAO. Voluntary Guidelines for Securing Sustainable Small-Scale Fisheries: In the Context of Food Security and Poverty Eradication; FAO: Rome, Italy, 2015; p. 18.

43. DFID. Sustainable Livelihoods-Building on Strengths; Department for International Development: London, UK, 2000.

44. Janssen, M.A.; Schoon, M.L.; Ke, W.; Börner, K. Scholarly networks on resilience, vulnerability and adaptation within the human dimensions of global environmental change. Glob. Environ. Chang. 2006, 16, $240-252$. [CrossRef]

45. Townsley, P. Review of coastal and marine livelihoods and food security in the Bay of Bengal Large Marine Ecosystem Region. In Bay of Bengal Large Marine Ecosystem Programme; The Innovation Centre, University of Exeter: Exeter, UK, 2004.

46. Tanner, T.M.; Hassan, A.; Islam, K.M.N.; Conway, D.; Mechler, R.; Ahmed, A.U.; Alam, M. ORCHID: Piloting Climate Risk Screening in DFID Bangladesh; Detailed Research Report; Institute of Development Studies: Brington, UK, 2007.

47. MOEF. National Adaptation Programme of Action (NAPA); Ministry of Environment and Forest, People's Republic of Bangladesh: Dhaka, Bangladesh, 2005.

48. Caesar, J.; Janes, T. Regional climate change over South Asia. In Ecosystem Services for Well-Being in Deltas: Integrated Assessment for Policy Analysis; Nicholls, R.J., Hutton, C.W., Neil Adger, W., Hanson, S.E., Munsur Rahman, M., Salehin, M., Eds.; Palgrave Macmillan: Cham, Switzerland, 2018; pp. 207-221.

49. IPCC. Climate Change 2014: Impacts, Adaptation, and Vulnerability. Part A: Global and Sectoral Aspects. Contribution of Working Group II to the Fifth Assessment Report of the Intergovernmental Panel on Climate Change; Field, C.B., Barros, V.R., Dokken, D.J., Mach, K.J., Mastrandrea, M.D., Bilir, T.E., Chatterjee, M., Ebi, K.L., Estrada, Y.O., Genova, R.C., et al., Eds.; Cambridge University Press: Cambridge, UK; New York, NY, USA, 2014.

50. Galego de Oliveira, A.; Bailly, D.; Cassemiro, F.A.; Couto, E.V.d.; Bond, N.; Gilligan, D.; Rangel, T.F.; Agostinho, A.A.; Kennard, M.J. Coupling environment and physiology to predict effects of climate change on the taxonomic and functional diversity of fish assemblages in the Murray-Darling Basin, Australia. PLoS ONE 2019, 14, e0225128. [CrossRef] [PubMed]

51. BMD. List of Major Cyclonic Storms from 1960 to 2017. Available online: http://live3.bmd.gov.bd/p/HistoricalCyclones (accessed on 5 March 2020).

52. Mome, M.A.; Officer, E.; Bhaban, M.; Arnason, R. The Potential of the Artisanal Hilsa Fishery in Bangladesh: An Economically Efficient Fisheries Policy; Fisheries Training Programme Final Project Report; United Nations University: Reykjavik, Iceland, 2007; p. 57.

53. Gag, P.L.; Donelson, J.M.; Dixson, D.L.; Endo, G.G. Effects of ocean acidification on the early life history of a tropical marine fish. Proceed. Royal Soc. B Biol. Sci. 2009, 276, 3275-3283.

54. Gagliano, M.; McCormick, M.I.; Meekan, M.G. Temperature- induced shifts in selective pressure at a critical developmental transition. Oecologia 2007, 152, 219-225. [CrossRef] [PubMed]

55. Islam, M.M.; Chuenpagdee, R. Threats of extreme events to the Bangladesh Sundarbans. In Global Change in Marine Systems: Societal and Governing Responses; Routledge: London, UK, 2017; pp. 171-182.

56. Vinagre, C.; Santos, F.D.; Cabral, H.N.; Costa, M.J. Impact of climate and hydrology on juvenile fish recruitment towards estuarine nursery grounds in the context of climate change. Estuar. Coast. Shelf Sci. 2009, 85, 479-486. [CrossRef] 
57. Cheung, W.W.; Dunne, J.; Sarmiento, J.L.; Pauly, D. Integrating ecophysiology and plankton dynamics into projected maximum fisheries catch potential under climate change in the Northeast Atlantic. ICES J. Mar. Sci. 2011, 68, 1008-1018. [CrossRef]

58. Mazumder, S.; De, M.; Mazlan, A.; Zaidi, C.; Rahim, S.; Simon, K. Impact of global climate change on fish growth, digestion and physiological status: Developing a hypothesis for cause and effect relationships. J. Water Clim. Chang. 2015, 6, 200-226. [CrossRef]

59. Burt, J.; Hinch, S.; Patterson, D. The importance of parentage in assessing temperature effects on fish early life history: A review of the experimental literature. Rev. Fish Biol. Fish. 2011, 21, 377-406. [CrossRef]

60. Ali, A.D.; Naser, M.N.; Bhaumik, U.; Hazra, S.; Bhattacharya, S.B. Migration, Spawning Patterns and Conservation of Hilsa Shad (Tenualosa ilisha) in Bangladesh and India; Academic Foundation; International Union for Conservation of Nature and Natural Resources (IUCN): New Delhi, India, 2014; p. 95.

61. Muhling, B.A.; Lee, S.K.; Lamkin, J.T.; Liu, Y. Predicting the effects of climate change on bluefin tuna (Thunnus thynnus) spawning habitat in the Gulf of Mexico. ICES J. Mar. Sci. 2011, 68, 1051-1062. [CrossRef]

62. CSIRO. Water Availability in the Murray-Darling Basin; A Report to the Australian Government from the CSIRO Murray-Darling Basin Sustainable Yields Project; CSIRO: Canberra, Australia, 2008.

(C) 2020 by the authors. Licensee MDPI, Basel, Switzerland. This article is an open access article distributed under the terms and conditions of the Creative Commons Attribution (CC BY) license (http://creativecommons.org/licenses/by/4.0/). 